\title{
Single institution best recommendation is HIPEC with cisplatin and docetaxel
}

\author{
Paul H. Sugarbaker ${ }^{1}$, Kurt Van der Speeten ${ }^{2}$ \\ ${ }^{1}$ MedStar Washington Hospital Center, Washington, DC, USA; ${ }^{2}$ Department of Surgery, Hospital Oost-Limburg, Genk, Belgium \\ Correspondence to: Paul H. Sugarbaker, MD. MedStar Washington Hospital Center, Washington, DC, USA. Email: Paul.Sugarbaker@outlook.com; \\ Kurt Van der Speeten. Department of Surgery, Hospital Oost-Limburg, Genk, Belgium. Email: Kurt.Vanderspeeten@zol.be. \\ Comment on: Ji ZH, Zhang Y, Li Y. Intra-operative hyperthermic intraperitoneal chemotherapy for prevention and treatment of peritoneal metastases \\ from gastric cancer: a narrative review. J Gastrointest Oncol 2021;12:S70-8.
}

Submitted Dec 16, 2020. Accepted for publication Mar 16, 2021.

doi: 10.21037/jgo-2020-13

View this article at: http://dx.doi.org/10.21037/jgo-2020-13

Zhong-He Ji and collaborators from Capital Medical University, Beijing, China worked hard to directly answer our request for an optimal HIPEC for gastric cancer with peritoneal metastases (1). They came to a conclusion that it was not easy to fulfill our request. The diversity of HIPEC regimens includes: The methodology (open vs. closed), single $v$ s. multiple chemotherapy agents, dose, temperature, carrier solution, and tolerance for adverse events. From their own data, the doublet they propose is cisplatin plus docetaxel at $43{ }^{\circ} \mathrm{C}$ for 60 minutes. Trials comparing the most promising HIPECs are "urgently needed".

\section{Acknowledgments}

Funding: None.

\section{Footnote}

Provenance and Peer Review: This article was commissioned by the editorial office, Fournal of Gastrointestinal Oncology for the focused issue "Intraperitoneal Chemotherapy for Peritoneal Metastases: HIPEC, EPIC, NIPEC, PIPAC and More". The article did not undergo external peer review.

Conflicts of Interest: Both authors have completed the ICMJE uniform disclosure form (available at http:// dx.doi.org/10.21037/jgo-2020-13). The focused issue was sponsored by the Peritoneal Surface Oncology Group International (PSOGI). Drs. PHS and KVDS served as the unpaid Guest Editors of the focused issue. The authors have no other conflicts of interest to declare.

Ethical Statement: The authors are accountable for all aspects of the work in ensuring that questions related to the accuracy or integrity of any part of the work are appropriately investigated and resolved.

Open Access Statement: This is an Open Access article distributed in accordance with the Creative Commons Attribution-NonCommercial-NoDerivs 4.0 International License (CC BY-NC-ND 4.0), which permits the noncommercial replication and distribution of the article with the strict proviso that no changes or edits are made and the original work is properly cited (including links to both the formal publication through the relevant DOI and the license). See: https://creativecommons.org/licenses/by-nc-nd/4.0/.

\section{References}

1. Ji ZH, Zhang Y, Li Y. Intra-operative hyperthermic intraperitoneal chemotherapy for prevention and treatment of peritoneal metastases from gastric cancer: a narrative review. J Gastrointest Oncol 2021;12:S70-8.

Cite this article as: Sugarbaker PH, Van der Speeten K. Single institution best recommendation is HIPEC with cisplatin and docetaxel. J Gastrointest Oncol 2021;12 (Suppl 1):S79. doi: 10.21037/jgo-2020-13 